\title{
RADIOACTIVITY IN MONOCALCIUM PHOSPHATE AND COMPLETE FEED MIXTURES FOR PIGS
}

\author{
Borjana Vranješ ${ }^{*}$, Branislava Mitrović ${ }^{1}$, Velibor Andrićc ${ }^{1}$ Jelena Ajtić ${ }^{1}$, Mila Vranješ² \\ ${ }^{1}$ Faculty of Veterinary Medicine, University of Belgrade, Belgrade, Serbia \\ ${ }^{2}$ Vinča Institute of Nuclear Sciences, University of Belgrade, Belgrade, Serbia
}

\begin{abstract}
Mineral additives, such as monocalcium phosphate, that are commonly used on pig farms, are obtained by processing phosphate mineral ore, and can contain high levels of ${ }^{23} \mathrm{U}$. Since ingestion is the main route of radioactive contamination of both animals and humans, the goal of this paper is to measure specific activity of natural and artificial radionuclides in monocalcium phosphate and complete feed mixtures for pigs. Mineral additives with high levels of natural radionuclides can contaminate complete feed mixtures making them unsuitable for use. Samples were collected from three different farms, and in total fifteen samples of monocalcium and forty five samples of complete feed mixture were measured. Samples of monocalcium phosphate show the ${ }^{238} U$ activity concentration of $13.2-$ $2097 \mathrm{~Bq} / \mathrm{kg}$. Other naturally occurring radionuclides are measured in monocalcium and the results give: $21.4-25.5$ $\mathrm{Bq} / \mathrm{kg}$ for ${ }^{40} \mathrm{~K}, 1.5-12.1 \mathrm{~Bq} / \mathrm{kg}$ for ${ }^{22} \mathrm{Ra}, 1.5-2.9 \mathrm{~Bq} / \mathrm{kg}$ for ${ }^{232} \mathrm{Th}$, and $1.5-10.8 \mathrm{~Bq} / \mathrm{kg}$ for ${ }^{214} \mathrm{Bi}$. These radionuclides are further measured in complete feed mixtures and only one sample shows elevated concentrations of ${ }^{238} \mathrm{U}(3.1 \mathrm{~Bq} / \mathrm{kg})$ and ${ }^{226} \mathrm{Ra}(3.5 \mathrm{~Bq} / \mathrm{kg})$. Potassium-4O is detected in all samples, with the specific activity range $208-329 \mathrm{~Bq} / \mathrm{kg}$, while other naturally occurring radionuclides and artificial radioceasium are below the detection limits.
\end{abstract}

Key words: Feed mixture, monocalcium phosphate, pigs, radionuclides

DOI: $10.21175 /$ RadProc.2017.25

\section{INTRODUCTION}

Ionising radiation, based on its origin and mode of occurrence, can be divided into naturally-occurring and artificial. All living organisms are constantly exposed to radiation from natural sources and the dose they receive can be increased through food and water intake [1]. Technological development has led to an increase of natural radioactivity through redistribution of naturally occurring radionuclides in the environment. This phenomenon is named TENORM (Technologically Enhanced Naturally Occurring Radioactive Material) and includes any naturally occurring radioactive material whose radionuclide concentration or potential for human exposure has been increased above levels encountered in the natural state by human activities. Some of the major TENORM sources are uranium mining, coal combustion, oil and natural gas production and processing, phosphate fertiliser and elemental-phosphorus production. The most important TENORM radionuclides are long-lived, naturally occurring ${ }^{\circ} \mathrm{K}$ and the isotopes of thorium, radium and uranium, as well as their radiologically important decay products [2].

Uranium belongs to a group of heavy metals with low radioactivity. Adverse effects on the human and animal organism are both toxic and radiological. Toxic effects are manifested on the kidneys as target organs, but as an alpha emitter with great ionisation power, uranium can cause severe damage to the whole organism. Nearly $66 \%$ of ingested uranium is deposited in the bones, the rest in the kidneys and liver, and a part is excreted by faces and urine [3]. The results obtained by Mitrovic et al. [4] showed that in broilers uranium primarily accumulates in kidney and liver compared with brain and muscles.

Decay products of ${ }^{238} \mathrm{U}$ are more important, particularly ${ }^{226} \mathrm{Ra}$ and its decay products (e.g., ${ }^{214} \mathrm{Bi}$ ) because of gamma ray emission [2]. Radium is an analogue of calcium, and in the body, it is incorporated in the bones of animals and humans (80\%) [1] Relevance of determining the specific activity of radium is based on these facts.

Thorium-232 is a metallic naturally occurring element that is radioactive [5]. In most soils the specific activity of thorium is $8-80 \mathrm{~Bq} / \mathrm{kg}$ were it is strongly sorbed to soil [5]. Thorium can form soluble complexes with ligands or ions in the soil, or became more soluble in low $\mathrm{pH}[2,5]$. The plant/soil ratio for ${ }^{232} \mathrm{Th}$ is less than 0.01 [5]. Because of its insolubility and very low specific activity thorium can be found in biological world in very small amounts [1]. Nevertheless, due to gamma radiation, the thorium decay chain has a greater dose rate than uranium [2]. Therefore, it is important to determine the specific activity of this radionuclide in foodstuff.

Potassium-40 is the predominant radionuclide in food and animal tissues, decaying by beta particles and gamma photons emission. In the body, potassium is under homeostatic control and is little influenced by environmental variations [2].

Radioceasium is analogue to potassium and has a similar physiological activity [1] which makes it the most significant anthropogenic radionuclide [6]. Adsorption of ${ }^{137 \mathrm{Cs}}$ by plants from soil is decreased if competing ions $\mathrm{K}$ and $\mathrm{Na}$ are present [7].Because of its long half-life (30 years) and tendency to replace 
potassium in the body [1], it is important to determine the specific activity of ${ }^{137} \mathrm{Cs}$ in feedstuff.

Phosphate fertilizers usually contain significant quantities of natural uranium and are extensively used in farming industry. Biotechnical production cycle includes crop production, animal feed, foodstuff of plant origin, farm animals, and products of animal origin. Agrotechnical methods in this cycle are used for improvement of production in order to obtain highquality biotechnical product (e.g. wheat, green leafy vegetables, roots and tubers, other vegetables and fruits milk, meat), whose main end consumers are humans. Radionuclides in this production process have a very rapid migration and it is very difficult to prevent their transfer through the food chain [8]. When considering the possibility of contamination of the production cycle, one should also bear in mind the contamination pathways of animals. An animal, the same as any other living organism on the planet, can be radioactively contaminated in three ways: inhalation of radioactive particles (15\%), transcutaneous when radioactive particles reach the skin (3-4\%), and ingestion of food and water (80\%) which is the most common way of contamination [1].

Pigs are monogastric animals, omnivores, and to develop normally and meet production requirements, they must take sufficient amounts of food that satisfies their daily energy needs. Meals should be well balanced and prepared from good quality ingredients [9]. Every meal should contain not only nutrients that provide energy, but also minerals, water, salt and vitamins that are essential components of the body [10]. Quality of life and production capacities can be increased with good quality meals. The main problem that occurs in pig nutrition is a deficit of minerals. Commonly used feeds are either deficient in minerals, or the minerals are in a form that is unavailable to pigs. One such mineral is phosphorus which plants usually have in sufficient quantities, but in an organic form, as phytine, which has an inefficient conversion rate for pigs (50\% or less). Therefore, meals or complete feed mixtures must contain mineral supplements, because they can be provided only through food [9].

The aim of this paper is to investigate the specific activity of naturally occurring and artificial radionuclides in mineral additives, in this case monocalcium phosphate, and complete feed mixtures.

\section{MATERIALS AND METHODS}

Samples of monocalcium phosphate and complete feed mixtures (CFM) for pigs in fattening, lactating sows and boars were collected from three different pig farms on the territory of Serbia. From each farm simple samples were collected randomly, five simple samples of monocalcium, and five samples of every complete feed mixture. Samples were brought to the laboratory of the Department of Radiobiology with Radiation Hygiene, Faculty of veterinary medicine, weighed and packed in $1 \mathrm{l}$ Marinelli beakers. After four weeks, which is the time necessary for achieving radioactive equilibrium, the content of radionuclides in these samples was determined by standard gamma spectrometry. Specific activity of naturally occurring and artificial radionuclides is reported as the arithmetic mean and the relevant standard deviation.
Activity concentrations of radionuclides in samples were determined by gamma-ray spectrometry on two HPGe detectors (ORTEC), with relative efficiency of 30 $\%$ and $36 \%$, with energy resolution of $1.73 \mathrm{keV}$ and 1.75 $\mathrm{keV}$ (1332.5 6oCo).

For detector efficiency calibration, a commercially available standard (supplied by the Czech Metrology Institute) with mixed radionuclides was used: ${ }^{241} \mathrm{Am}$, ${ }^{133} \mathrm{Ba},{ }^{109} \mathrm{Cd},{ }^{139} \mathrm{Ce},{ }^{57} \mathrm{Co},{ }^{60} \mathrm{Co},{ }^{137} \mathrm{Cs},{ }^{54} \mathrm{Mn},{ }^{113} \mathrm{Sn},{ }^{85} \mathrm{Sr}$, ${ }^{88} \mathrm{Y}$, dispersed in silicone resin in Marinelli beaker, density $(0.98 \pm 0.01) \mathrm{g} / \mathrm{cm}^{3}$, volume $1 \mathrm{l}$. Radioactive material is homogenously dispersed in silicone resin.

The counting time for the samples of monocalcium phosphate was $250000 \mathrm{~s}$, and for samples of completed feed mixtures $60000 \mathrm{~s}$. The minimum detectable activity $M D A$ for each radionuclide was determined using the following equation, for live times of 250000 and $60000 \mathrm{~s}$ (GammaVision $(\mathrm{R}-32,2006$ ):

$$
M D A=\frac{2 \times\left(1+\sqrt{1+2 B_{1}}\right)}{\varepsilon \times I \times T \times M}
$$

where $B_{1}$ is background reported in the identified peak summary (counts), $\varepsilon$ is absolute efficiency of detector, $I$ is the gamma emission probability, $T$ is counting time, and $M$ is the mass of the sample (in $\mathrm{kg}$ ). The minimum detectable activity of ${ }^{40} \mathrm{~K},{ }^{137} \mathrm{Cs},{ }^{23}{ }^{8} \mathrm{U},{ }^{226} \mathrm{Ra},{ }^{232} \mathrm{Th}$ and ${ }^{214} \mathrm{Bi}$ in samples of monocalcium phosphate was: 0.8 $\mathrm{Bq} / \mathrm{kg}$, 0.1 Bq/kg, $1.4 \mathrm{~Bq} / \mathrm{kg}$, $1.4 \mathrm{~Bq} / \mathrm{kg}$, 0.5 Bq/kg, and $0.3 \mathrm{~Bq} / \mathrm{kg}$, respectively; and for samples of completed feed mixtures: $1.3 \mathrm{~Bq} / \mathrm{kg}$, 0.1 Bq/kg, 2.5 Bq/kg, 2.5 $\mathrm{Bq} / \mathrm{kg}, 0.8 \mathrm{~Bq} / \mathrm{kg}$ and $0.8 \mathrm{~Bq} / \mathrm{kg}$, respectively.

The analysis of ${ }^{23} 8 \mathrm{U}$ by gamma spectrometry relies on the hypothesis of equilibrium conditions between the parent nuclide ${ }^{238} \mathrm{U}$ and its daughters, ${ }^{234} \mathrm{Th}(63.2$ $\mathrm{keV})$ and ${ }^{234 \mathrm{~m}} \mathrm{~Pa}(1001 \mathrm{keV})$. The ${ }^{226} \mathrm{Ra}$ activity was determined by its (from the gamma line of $186.1 \mathrm{keV}$ corrected for ${ }^{235 \mathrm{U}}$, and ${ }^{226} \mathrm{Ra}$ ) daughters in equilibrium, ${ }^{214} \mathrm{Bi}(609.3,1120.2$ and $1764.5 \mathrm{keV})$ and ${ }^{214} \mathrm{~Pb}(351.9$ $\mathrm{keV}$ ). In the case of ${ }^{232} \mathrm{Th}$, three photo peaks of ${ }^{228} \mathrm{Ac}$ (338, 911.2 and $969 \mathrm{keV})$ were used. The activities of ${ }^{40} \mathrm{~K}$ and ${ }^{137} \mathrm{Cs}$ were derived from the $1460.8 \mathrm{keV}$ and $661.66 \mathrm{keV}$ gamma lines, respectively.

The analysis of each measured gamma ray spectrum was carried out by a software program ORTEC GammaVision for Windows model A66-B32 version 6.06. All obtained results are expressed as (mean \pm standard deviation).

Derived concentrations of radionuclides $\left(I K_{h}\right)$ in monocalcium and complete feed mixtures were calculated using the formula given in Article 6 of the Rulebook on limits of radionuclides content in drinking water, foodstuffs, feeding stuffs, medicines, general use products, construction materials and other goods that are put on market [11]:

$$
I K_{h}=\frac{G D}{e(g)_{m g n} \times m}
$$

where $G D$ is the limit value of effective dose for an individual and a value of $0.1 \mathrm{mSv}$ is taken [12]; $e(g)$ is the expected effective dose for unit intake of radionuclide through ingestion: $4.5 \times 10^{-8} \mathrm{~Sv} / \mathrm{Bq}$ for ${ }^{238} \mathrm{U}, 2.8 \times 10^{-7} \mathrm{~Sv} / \mathrm{Bq}$ for ${ }^{226} \mathrm{Ra}$, and $2.3 \times 10^{-7} \mathrm{~Sv} / \mathrm{Bq}$ for ${ }^{232} \mathrm{Th}$ [11]; $m$ is the amount of foodstuff that an individual takes in one year (in kg) [12]. 


\section{RESULTS AND DISCUSSION}

Main sources of calcium and phosphorus in pig's diet are mono- and dicalcium phosphate [9]. These supplements are obtained by processing phosphorus ore, and can contain large amounts of uranium, thus posing as a potential source of radioactive contamination for both animals and humans [13].

The harmful effects of uranium are mainly due to its chemical toxicity. In broilers after a 7-day contamination with $25 \mathrm{mg}$ of uranyl nitrate hexahydrate per day, histopathological changes were observed in small intestine, liver, and kidney in the form of necrosis of intestinal villi, oedema and cytoplasmic vacuolation of hepatocytes, and dystrophic changes in the kidney tubules epithelium [4]. Results obtained in study on Beagle dogs indicated that through prolonged ingestion uranium was accumulated and distributed both in bone and bone marrow, saturation is reached only after about 10 years [14].

Fattening of pigs, counting from the first day of birth, lasts six months (180 days) during which time they are fed an average of $2.6 \mathrm{~kg}$ of feed per day $(\mathrm{kg} / \mathrm{d})$. Weaning of piglets starts in between 10 and 14 days of age. Monocalcium phosphate is usually added to every kilogram of the meal and complete feed mixture in a quantity of $0.5^{-1 \%}$ [9], resulting in a daily intake of $0.013-0.026 \mathrm{~kg}$.

Article 8 of the Rulebook on limits of radionuclides content in drinking water, foodstuffs, feeding stuffs, medicines, general use products, construction materials and other goods that are put on the market states that the limits of the content of radionuclides in feed for animals are equal to the limits defined for human food [7]. Using equation (2), the concentration limits for ${ }^{238} \mathrm{U},{ }^{226} \mathrm{Ra}$ and ${ }^{232} \mathrm{Th}$ in monocalcium phosphate over 166 days and assuming daily intake of 0.013-0.026 kg were calculated. Weaning period of 14 days was excluded. The results gave $527-1054 \mathrm{~Bq} / \mathrm{kg}$ for ${ }^{238} \mathrm{U}, 83-166 \mathrm{~Bq} / \mathrm{kg}$ for ${ }^{226} \mathrm{Ra}$ and $101-202 \mathrm{~Bq} / \mathrm{kg}$ for ${ }^{232} \mathrm{Th}$, respectively.

Table 1 shows the results for specific activities of natural and artificial radionuclides in the samples of monocalcium phosphate collected on the three farms. The specific activities were: $21.4-25.5 \mathrm{~Bq} / \mathrm{kg}, \quad 1.5^{-}$ $12.1 \mathrm{~Bq} / \mathrm{kg}, 1.5-2.9 \mathrm{~Bq} / \mathrm{kg}$ and $1.4-10.8 \mathrm{~Bq} / \mathrm{kg}$ for ${ }^{40} \mathrm{~K}$, ${ }^{226} \mathrm{Ra},{ }^{232} \mathrm{Th}$, and ${ }^{214} \mathrm{Bi}$, respectively.

Table 1. Specific activity $(\mathrm{Bq} / \mathrm{kg})$ of natural and artificial radionuclides in monocalcium phosphate

\begin{tabular}{|l|l|l|l|}
\hline & Farm I & Farm II & Farm III \\
\hline${ }^{40} \mathrm{~K}$ & $21.4 \pm 2.1$ & $21.9 \pm 2.1$ & $25.5 \pm 2.5$ \\
\hline${ }^{137} \mathrm{Cs}$ & $<0.1$ & $<0.1$ & $<0.1$ \\
\hline${ }^{238} \mathrm{U}$ & $2097 \pm 209$ & $1574 \pm 157$ & $13.2 \pm 1.3$ \\
\hline${ }^{226} \mathrm{Ra}$ & $1.5 \pm 0.1$ & $5.6 \pm 0.5$ & $12.1 \pm 1.2$ \\
\hline${ }^{232} \mathrm{Th}$ & $1.5 \pm 0.2$ & $2.4 \pm 0.3$ & $2.9 \pm 0.2$ \\
\hline${ }^{214} \mathrm{Bi}$ & $1.4 \pm 0.1$ & $6.7 \pm 0.6$ & $10.8 \pm 1.0$ \\
\hline
\end{tabular}

All monocalcium phosphate samples which were collected from farms I and II had a higher specific activity of ${ }^{238} \mathrm{U}(1574-2097 \mathrm{~Bq} / \mathrm{kg})$ which exceed the calculated limit for ${ }^{238} \mathrm{U}$ and thus made them unsuitable for use as a mineral supplement.

Artificial radioceasium was below the detection limits in all samples of monocalcium phosphate.
Samples that exceed the limits for uranium should be excluded from use or replaced with monocalcium phosphate with lower activities like the one from farm III. Other sources of $\mathrm{Ca}$ and $\mathrm{P}$ can be used e.g. bone meal in which phosphorus is more available for pigs, and has a great significant in diet of monogastric animals [9].

Complete feed mixtures facilitate intensive breeding of pigs because they contain all the nutrients and minerals that are essential to meet pigs' daily needs. Depending on the final product, there are four types of pig fattening: meaty, semi fat, full fat and bacon. In all cases, the fattening takes up to six months, except bacon fattening, which takes 7-7.5 months. Meaty fattening is the most common and economical. One of the most important factors that affect the success and quality of the end product is the composition and size of the meal, which also affects the very length of fattening. Pigs in meaty fattening eat an average of $2.6 \mathrm{~kg} / \mathrm{d}$, in semi fat $3 \mathrm{~kg} / \mathrm{d}$, and in full fat $3.6 \mathrm{~kg} / \mathrm{d}$ of food [9]. Using equation (2), the limits for the ${ }^{238} \mathrm{U}$ and ${ }^{226} \mathrm{Ra}$ concentrations in complete feed mixtures for pigs were calculated for the period of 166 and 216 days (weaning period of 14 days is not included). The calculated limit for ${ }^{238} \mathrm{U}$ is $2.9-5 \cdot 3 \mathrm{~Bq} / \mathrm{kg}$ and for ${ }^{226} \mathrm{Ra}$ is $0.5^{-0} 0.8 \mathrm{~Bq} / \mathrm{kg}$.

Specific activity of naturally occurring radionuclides and artificial radioceasium in complete feed mixtures for pigs in fattening are shown in Table 2.

Potassium-40 was detected in all samples and its specific activity ranged from 208-329 Bq/ kg (Table 2). Higher level of uranium was detected in the sample from farm I but its activity $(3.1 \mathrm{~Bq} / \mathrm{kg}$ ) was within the permitted range. In the same sample, concentration of ${ }^{226} \mathrm{Ra}(3.5 \mathrm{~Bq} / \mathrm{kg})$ exceeded the calculated limit, which made this sample unsuitable for feeding pigs. The specific activities of ${ }^{232} \mathrm{Th}$ and ${ }^{214} \mathrm{Bi}$, as well as of radioceasium, were below the detection limits.

Table 2.Specific activity $(\mathrm{Bq} / \mathrm{kg})$ of natural and artificial radionuclides in complete feed mixtures for pigs in fattening

\begin{tabular}{|l|l|l|l|}
\hline & Farm I & Farm II & Farm III \\
\hline${ }^{40} \mathrm{~K}$ & $222 \pm 5$ & $208 \pm 5$ & $329 \pm 10$ \\
\hline${ }^{137} \mathrm{Cs}$ & $<0.1$ & $<0.1$ & $<0.2$ \\
\hline${ }^{238} \mathrm{U}$ & $3.1 \pm 1.2$ & $<1.5$ & $<2.1$ \\
\hline${ }^{226} \mathrm{Ra}$ & $3.5 \pm 0.9$ & $<1.7$ & $<2.1$ \\
\hline${ }^{232} \mathrm{Th}$ & $<0.7$ & $<0.3$ & $<0.5$ \\
\hline${ }^{214} \mathrm{Bi}$ & $<0.2$ & $<0.2$ & $<0.2$ \\
\hline
\end{tabular}

Specific activities of natural and artificial radionuclides in complete feed mixtures for lactating sows and boars are shown in Table 3 .

Table 3. Specific activity $(\mathrm{Bq} / \mathrm{kg})$ of natural and artificial radionuclides in complete feed mixtures for lactating sows and boars

\begin{tabular}{|l|l|l|l|l|}
\hline & \multicolumn{2}{l|}{ Lactating sows } & \multicolumn{2}{l|}{ Boars } \\
\hline & Farm I & Farm III & Farm I & Farm III \\
\hline${ }^{40} \mathrm{~K}$ & $220 \pm 1$ & $262 \pm 6$ & $213 \pm 7$ & $274 \pm 6$ \\
\hline${ }^{137} \mathrm{Cs}$ & $<0.1$ & $<0.1$ & $<0.1$ & $<0.1$ \\
\hline${ }^{238} \mathrm{U}$ & $<1.5$ & $<1.3$ & $<1.1$ & $<1.5$ \\
\hline${ }^{226} \mathrm{Ra}$ & $<1.6$ & $<1.4$ & $<1.1$ & $<1.6$ \\
\hline${ }^{232} \mathrm{Th}$ & $<0.4$ & $<0.3$ & $<0.5$ & $<0.4$ \\
\hline${ }^{214} \mathrm{Bi}$ & $<0.2$ & $<0.1$ & $<0.7$ & $<0.2$ \\
\hline
\end{tabular}

Potassium-40 was the dominant radionuclide detected in those samples. Its specific activity ranged 
from $213-274 \mathrm{~Bq} / \mathrm{kg}$. Specific activity of other naturally occurring radionuclides and radioceasium was below the maximum detectable activity. Gamma spectrometry of the sampled complete feed mixtures for these pig categories showed they were radiologically safe for use.

\section{CONCLUSION}

Gama spectrometry analysis of the samples of mineral supplements and complete feed mixtures used in pig fattening offers an insight into the burden with natural and artificial radionuclides encountered in the production process. Our study showed that some radiologically unsafe feed products were used in pig fattening. To avoid future cases of such risk, continuous monitoring of the row materials used for the production process of monocalcium should be introduced. The monitoring could detect a source of natural and artificial radionuclides, and in time prevent their entry into the production chain. Mineral supplements and complete mixtures for pigs which exceed the maximum permitted limits of radioactive elements should be either diluted with adequate nutrients ore excluded from use and replaced by them. Also adsorbents could be added to the mix. These measures could significantly improve the quality of life of each individual pig, and thus the quality of the final product whose main consumers are men.

Acknowledgment: This paper is a part of the research done within the projects "Development of technology and products based on mineral raw materials and biomass for protecting the food resources" (No. TR31003) and "Climate changes and their influence on the environment: impacts, adaptation and mitigation" (No. 43007) financed by the Ministry of Education, Science and Technological Development of the Republic of Serbia (2011-2017).

\section{REFERENCES}

1. L. Saračević, Veterinarska radiobiologija sa radijacionom higijenom, Sarajevo, Bosna i Hercegovina: DES Sarajevo, 1999. (L. Saračević, Veterinary radiobiology with radiation hygiene, Sarajevo, Bosnia and Herzegovina, DES Sarajevo, 1999.)

2. "Evaluation of Guidelines for Exposures to Technologically Enhanced Naturally Occurring Radioactive Materials," Committee on Evaluation of EPA Guidelines for Exposure to Naturally Occurring Radioactive Materials, Washington DC, USA, 1999. Retrieved from:

https://www.nap.edu/catalog/6360/evaluation-ofguidelines-for-exposures-to-technologically-enhancednaturally-occurring-radioactive-materials

Retrieved on: Sep. 10, 2016

3. Toxicological profile for uranium, U.S. Department of Health and Human Services, Agency for Toxic Substances and Disease Registry, Atlanta, (GE), USA, 2013.

Retrieved from:

https://www.atsdr.cdc.gov/toxprofiles/tp150.pdf

Retrieved on: Sep. 10, 2016

4. B. Mitrović et al., "Uranium distribution in broiler organs and possibilities for protection", Radiation and Environmental Biophysics, vol. 53, no. 1, pp 151-157, Mar. 2014.

DOI: $10.1007 /$ soo411-013-0496-3

PMid: 24096927
5. Toxicological profile for thorium, U.S. Department of Health and Human Services, Agency for Toxic Substances and Disease Registry, Atlanta, (GE), USA, 1990.

Retrieved from:

https://www.atsdr.cdc.gov/toxprofiles/tp147.pdf

Retrieved on: April 14, 2017

6. M. Momčilović, S. Dragović, "Radioaktivnost zemljišta severozapadnog dela stare planine," u Zbornik radova XXIV simpozijuma za zaštitu od zračenja Srbije i Crne Gore, Zlatibor, Srbija, 2007, pp 29-32. (M. Momčilović, S. Dragović, "Radioactivity of soils from north-west side of Stara planina mountain," in Proc. of the XXIV Symposium on Radiation Protection of Serbia and Montenegro, Zlatibor, Serbia, 2007, pp 29-32.)

Retrieved from:

http://www.iaea.org/inis/collection/NCLCollectionStore LPublic/39/066/39066543.pdf

Retrieved on: Jan. 25, 2017

7. G. Porêba, A. Bluszcz, Z. Śnieszko, "Concentration and vetrtical distribution of ${ }^{137} \mathrm{Cs}$ in agricultural and undisturbed soils from Chechło and Czarnocin areas," Geochronometria - Journal on Methods and Applications of Absolute Chronology, vol. 22, pp. 67-72, 2003

Retrieved from:

http://www.geochronometria.pl/pdf/geo_22/Geo22_9. pdf

Retrieved on: Sep. 15, 2016

8. B. Petrović, R. Mitrović, Radijaciona zaštita u biotehnologiji, Beograd, Jugoslavija: DP Institut za mlekarstvo, 1994. (B. Petrović, R. Mitrović, Radiation protection in biotechnology, Belgrade, Yugoslavia: DP Institute for dairy, 1994.)

9. N. Ševković, S. Pribićević, I. Rajić, Ishrana domaćih životinja, Beograd, Jugoslavija: Naučna knjiga, 1991. (N. Sevković, S. Pribićević, I. Rajić, Nutrition of domestic animals, Belgrade, Yugoslavia: Naučna knjiga, 1991.)

10. V. Stojić, "Energetski i kvantitativni metabolizam," u Veterinarska fiziologija, Beograd, Srbija: Naučna KMD, 2004, gl. 7, od. 7, str. 314-343. (V. Stojić, "Energy and quantitative metabolism," in Veterinary physiology, Belgrade, Serbia: Naučna KMD, 2004, ch. 7, sec. 7, pp. 314-343.)

11. Pravilnik o granici sadržaja radionuklida u vodi za piće, životnim namirnicama, stočnoj hrani, lekovima, predmetima opšte upotrebe, građevinskom materijalu i drugoj robi koja se stavlja u promet, Službeni glasnik Republike Srbije (br. 86/11 i 97/13, od 18.11.2011. i 6.11.2013), Beograd, Srbija, 2013. (Rulebook on limits of radionuclides content in drinking water, foodstuffs, feeding stuffs, medicines, general use products, construction materials and other goods that are put on market, Official Gazette of Republic of Serbia (no. 86/2011 and 97/2013, from Nov. 18, 2011 and Nov. 6, 2013.), Belgrade, Serbia, 2013.)

Retrieved from:

http://www.srbatom.gov.rs/srbatom/doc/vazeca akta/ pravilnik\%200\%20granicama\%20sadrzaja\%2oradionukl ida\%20u\%20...\%20(sl.\%20glasnik\%2ors,\%20br.\%20862011\%20i\%2097-2013)\%20-\%2olat.pdf

Retrived on: Sep. 10. 2016

12. Pravilnik o granicama radioaktivne kontaminacije lica, radne $i$ životne sredine $i$ načinu sprovođenja dekontaminacije, Službeni glasnik Republike Srbije (br. 38/11 od 31.05.2011), Beograd, Srbija, 2011. (Rulebook on limits of radioactive contamination of people, work and living environment and ways of performing decontamination, Official Gazette of the Republic of Serbia (no. 38/2011, from May 31, 2011.), Belgrade, Serbia, 2011.)

Retrieved from:

http://www.srbatom.gov.rs/srbatom/doc/vazeca akta/ pravilnik\%200\%20granicama\%20radioaktivne\%2okont aminacije\%2olica,\%2oradne\%20i\%20zivotne\%2osredin e\%20i\%20nacinu\%20sprovodjenja\%2odekontaminacije 
\%20(sl.\%20glasnik\%2ors,\%20br.\%2038-2011)\%20\%20lat.pdf

Retrieved on: Sep. 10, 2016

13. B. Mitrović, G. Vitorović, M. Stojanović, D. Vitorović, "Radioaktivnost fosfatnih mineralnih proizvoda", Vet. Glasnik, vol. 65, no. 1-2, pp. 133 -140, 2011. (B. Mitrović, G. Vitorović, M. Stojanović, D. Vitorović, "Radioactivity of phosphate mineral products," Vet. Gazette, vol. 65, no. 1-2, pp. $133-140,2011$.)

DOI: $10.2298 /$ vetgl1102133M
14. J. D. T. Arruda-Neto et al., "Long-term accumulation and microdistribution of uranium in bone and marrow of beagle dogs", International Journal of Radiation Biology, vol. 8o, no. 8, pp 565-575, Apr. 2004.

DOI: $10.1080 / 09553000410001723884$

PMid: 15370968 